\title{
2-Pyrrolidinones and 3-Pyrrolin-2-ones: A Study on the Chemical Reactivity of These Structural Moieties
}

\author{
José C. F. Alves \\ Núcleo de Pesquisas de Produtos Naturais, Centro de Ciências da Saúde, Bloco H, Universidade Federal do Rio de Janeiro, \\ 21941-590 Rio de Janeiro, RJ, Brazil \\ Correspondence should be addressed to José C. F. Alves, alvesjcf@yahoo.com.br
}

Received 28 April 2011; Revised 23 June 2011; Accepted 29 June 2011

Academic Editor: W. Billups

Copyright ( $\odot 2011$ José C. F. Alves. This is an open access article distributed under the Creative Commons Attribution License, which permits unrestricted use, distribution, and reproduction in any medium, provided the original work is properly cited.

The chemical reactivity of 2-pyrrolidinones and 3-pyrrolin-2-ones was evaluated in reactions of addition, nucleophilic substitution, elimination, and reduction as well as the protection of the lactamic nitrogen.

\section{Introduction}

In connection with our studies on the syntheses of potentially bioactive 2-pyrrolidinones and 3-pyrrolin-2-ones [1], we describe in this paper the results of the performed study on the chemical reactivity of these structural moieties in reactions of addition, nucleophilic substitution, elimination, and reduction as well as the protection of the lactamic nitrogen.

\section{Results and Discussion}

2.1. Reactions of Enolates Derived from 2-pyrrolidinone and N-tert-butoxycarbonyl-2-pyrrolidinone with Iodine and Diphenyl Disulfide. For execution of the reactions described in Scheme 1, we used as starting material the commercial reagent 2-pyrrolidinone(1), and for protection of the lactamic nitrogen of 1 , we planned to use the electron withdrawing group tert-butoxycarbonyl (Boc). This choice was due to the facility to be removed and also because this group increases the acidity of the hydrogens alpha to the carbamate group [2]. This enhancement of reactivity of the alpha hydrogens, in basic conditions, would be useful in posterior reactions. Thus, the treatment of $\mathbf{1}$ with a suspension of $\mathrm{NaH}$ in THF followed by reaction with $(\mathrm{Boc})_{2} \mathrm{O}[3]$ generated a compound characterized by ${ }^{1} \mathrm{H}$ NMR as the pyrrolidinone 2. The substance 2 was partially converted to a product identified by ${ }^{1} \mathrm{H}$ NMR as the thiophenoxylactam 3 , as result of alpha deprotonation of the carbamate of 2 with LDA solution [4], followed by nucleophilic substitution of the generated lithium enolate with diphenyl disulfide [5]. At the ${ }^{1} \mathrm{H}$ NMR spectrum of $\mathbf{3}$, signals were detected relative to two isomers in the proportion $(10: 1)$ measured by integrals relative to methyls of the groups tert-butoxycarbonyl at $\delta$ 1.52 (major isomer) and $\delta 1.43$ (minor isomer).

The isomers $\mathbf{4 a - b}$, characterized by ${ }^{1} \mathrm{H}$ NMR (Table 2), were obtained by addition reaction of iodine to silyl enol ether [6] derived from 2-pyrrolidinone(1) (Scheme 1). The moderate yield of this reaction $(25 \%)$, in relation to high yields described for iodination of silyl enol ethers derived from $\epsilon$-caprolactams [7] and $\delta$-valerolactams [6], was attributed to the high tension of the $\gamma$-lactamic ring of 1 turning it more reactive and, therefore, susceptible to the formation of byproducts.

2.2. Elimination Reactions of Hydrogen Iodide on 3-iodine-2pyrrolidinone. The study of elimination of hydrogen iodide on 3-iodine-2-pyrrolidinone was based on a method of dehydrohalogenation reported in the literature [8]. The results from that study, performed with the pyrrolidinones $\mathbf{4 a - b}$, are described in Scheme 2 and Table 1.

After the respective times of reaction described in Table 1, crude products were isolated, filtered over column chromatography of silica gel, and then analysed by ${ }^{1} \mathrm{H}$ NMR. The signals of hydrogens relative to elimination product 5 were not observed at the spectrum of experiment 1 . However, 


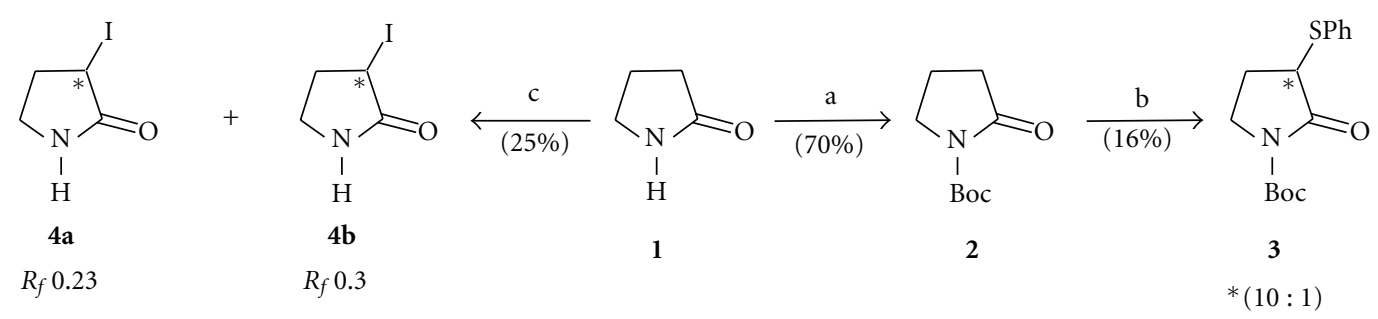

$(5: 1)$

Scheme 1: Reagents and conditions: (a) (i) $\mathrm{NaH}$ (1.2 equiv), THF (r.t., $15 \mathrm{~min}$ ), (ii) (Boc) ${ }_{2} \mathrm{O}$ (1.2 equiv, r.t., $40 \mathrm{~min}$ ); (b) (i) LDA (1.4 equiv,

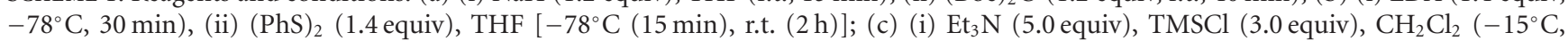
$10 \mathrm{~min})$, (ii) $\mathrm{I}_{2}\left(2.0\right.$ equiv, $\left.0^{\circ} \mathrm{C}, 2 \mathrm{~h}\right)$.

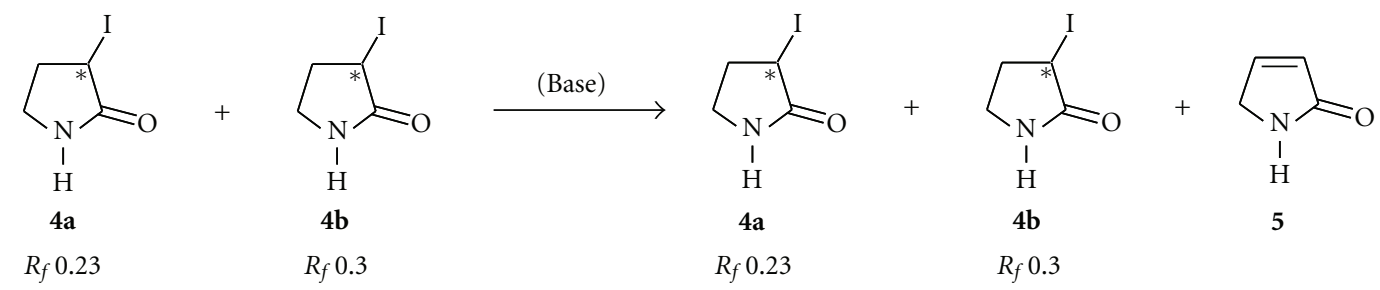

Scheme 2: Reagents: Experiment 1: 4 (1.0 equiv), LiCl (5.0 equiv); Experiment 2-3: 4 (1.0 equiv), Et ${ }_{3} \mathrm{~N}$ (5.0 equiv).

we verified a larger proportion of the thermodynamic isomer $\mathbf{4 b}$ in relation to the kinetic isomer $4 \mathbf{a}$ previously obtained at low temperature in the experiment described in Scheme 1. In experiments 2 and 3 where there was substitution of $\mathrm{LiCl}$ for a stronger base $\left(\mathrm{Et}_{3} \mathrm{~N}\right)$, we observed, in their ${ }^{1} \mathrm{H} \mathrm{NMR}$ spectra, signals relative to olefinic hydrogens $\mathrm{C} 3-\mathrm{H}$ and $\mathrm{C} 4-$ $\mathrm{H}$ of the substance 5 at $\delta 6.1$ and $7.1 \mathrm{ppm}$, respectively. At the spectrum of product from experiment 3 , where the reaction was accomplished with heating, we verified the absence of signal relative to hydrogen $\mathrm{C} 3-\mathrm{H}$ of the isomer $4 \mathrm{a}$ indicating total isomerization of $\mathbf{4 a}$ to $\mathbf{4 b}$.

2.3. Reactions of Reduction of the Carbamate and Aldol Addition on N-tert-butoxycarbonyl-2-pyrrolidinone. We used as starting material in these reactions the pyrrolidinone 2 , previously obtained in the conditions described in Scheme 1, and the reaction conditions for execution of this study were based on procedures reported in the literature (Scheme 3). Thus, $\mathrm{NaBH}_{4}$ in methanol was used for reduction of the carbamate at lactamic ring of the pyrrolidinone 2 [9]. The product from this reaction was characterized by ${ }^{1} \mathrm{H}$ NMR as the hemiaminal 6 . The mixture of isomers 7 , characterized by ${ }^{1} \mathrm{H}$ NMR, was obtained by aldol addition of enolate derived from the pyrrolidinone 2 to benzaldehyde [10].

2.4. Evaluation of the Reactivity of N-benzyl-3-pyrrolin-2one in Reactions of Reduction and Additions of Carbanion and Benzylamine. For execution of the reactions described in Scheme 4, we used as substrate $N$-benzyl-3-pyrrolin2 -one(8), which was previously obtained [1]. Thus, the treatment of $\mathbf{8}$ with TMSCl followed by reaction with the Grignard reagent $\mathrm{PhMgBr}$ and $\mathrm{CuBr} \cdot \mathrm{SMe}_{2}$ [11-13] generated a product identified by ${ }^{1} \mathrm{H}$ NMR, IR, and LRMS as the hemiaminal $\mathbf{9}$. The compound 10 , identified by ${ }^{1} \mathrm{H}$
NMR, was obtained by hydrogenation of $\mathbf{8}$ with hydrogen and the Pearlman catalyst $\mathrm{Pd}(\mathrm{OH})_{2} / \mathrm{C}$ [14]. The reaction of 8 with $S$ - $\alpha$-methylbenzylamine generated a complex mixture of substances. After a detailed analysis of ${ }^{1} \mathrm{H}$ NMR, ${ }^{13} \mathrm{C}$ NMR, ${ }^{1} \mathrm{Hx}{ }^{1} \mathrm{H}$-Cosy, HETCOR, IR and GC/MS spectra, we propose the structure of the probable isomers 11-13 as products of that reaction, resulting from the speculative mechanism depicted in Scheme 5. The proposition of the substances 1113 as the probable products from that reaction was reinforced at the GC/MS spectra by the peaks at $\mathrm{m} / \mathrm{z} 281\left(T_{R} 2.1,7.4\right.$ and $8.4 \mathrm{~min})$, attributed to the protonated $[\mathrm{M}+\mathrm{H}]^{+}$ions of that mixture of isomers.

The reactions described in Scheme 4 clearly show the low reactivity of lactam $\mathbf{8}$ in conjugate addition reactions of carbanion (condition a) and amine (condition c). In condition a the addition of TMSCl, to the reaction medium, generally used to activate the C-4 position to the nucleophilic attack of carbanion, was not able to do this; the substrate $\mathbf{8}$ was reduced in situ yielding compound $\mathbf{9}$. In condition $\mathbf{c}$ lactam 8 was totally inert to the conjugate addition reaction of amine, furnishing probable products of opening of the lactamic ring. There was evidence of condition $\mathbf{b}$, the better reactivity of double bond $\mathrm{C} 3-\mathrm{C} 4$ in relation to benzyl group attached to lactamic nitrogen in hydrogenation reaction, using a specific catalyst for hydrogenolysis of benzyl group (the Pearlman catalyst).

2.5. Reinvestigation of the Byproduct Obtained in the Protection Reaction of the Lactamic Nitrogen on 3-pyrrolin-2-one. In previous publication [1] we described the protection of the lactamic nitrogen on 3-pyrrolin-2-one (5) with (Boc) ${ }_{2} \mathrm{O}$ in a multigram scale $(4.7 \mathrm{~g}$ of $\mathbf{5})$ and $40 \%$ yield. In this paper we describe the results of this reaction performed in milligram scale $(0.65 \mathrm{~g}$ of 5 ) (Scheme 6$)$. We obtained 
TABLE 1: Evaluation of the elimination reactions performed with lactam 4.

\begin{tabular}{|c|c|c|c|c|c|c|c|}
\hline Experiment & Substrate (proportion) & Base & Solvent & Temperature $\left({ }^{\circ} \mathrm{C}\right)$ & Time $(\mathrm{h})$ & Products (proportion) ${ }^{\mathrm{a}}$ & $(\%)^{\mathrm{b}}$ \\
\hline 1 & $4 a+4 b(5: 1)$ & $\mathrm{LiCl}$ & DMF & 100 & 5 & $4 a+4 b(1: 10)$ & 40 \\
\hline 2 & $4 a+4 b(5: 1)$ & $\mathrm{Et}_{3} \mathrm{~N}$ & $\mathrm{CH}_{3} \mathrm{CN}$ & 25 & 72 & $\mathbf{4 a}+\mathbf{4 b}+\mathbf{5}(1: 5: 1)$ & 41 \\
\hline 3 & $4 \mathbf{a}+\mathbf{4 b}(5: 1)$ & $\mathrm{Et}_{3} \mathrm{~N}$ & $\mathrm{CH}_{3} \mathrm{CN}$ & 85 & 3 & $\mathbf{4 b}+\mathbf{5}(2: 1)$ & 40 \\
\hline
\end{tabular}

${ }^{\mathrm{a}}$ The proportion of products was measured by integrals relative to the signals of hydrogen $\mathrm{C} 3-\mathrm{H}\left({ }^{1} \mathrm{H} \mathrm{NMR}\right) .{ }^{\mathrm{b}}$ After filtration over column of silica gel.

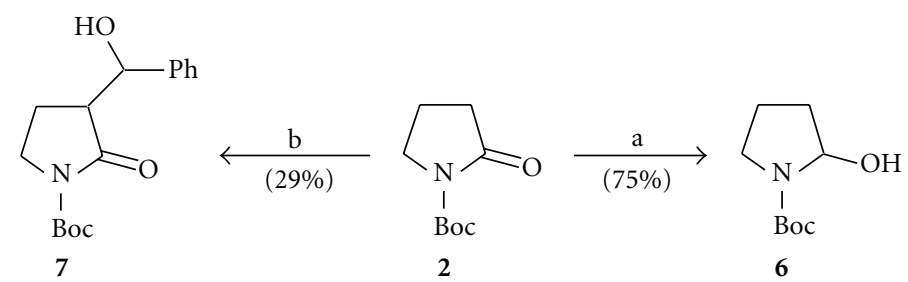

Scheme 3: Reagents and conditions: (a) $\mathrm{NaBH}_{4}$ (1.1 equiv), $\mathrm{MeOH}$ (r.t., 5 h); (b) (i) LDA (1.1 equiv), $\mathrm{THF}\left(-78^{\circ} \mathrm{C}, 30 \mathrm{~min}\right),($ ii) $\mathrm{PhCHO}$ [1.1 equiv, $-78^{\circ} \mathrm{C}(2.5 \mathrm{~h})$, r.t. $\left.(1 \mathrm{~h})\right]$.<smiles>O=C1CCCN1Cc1ccccc1</smiles>

10

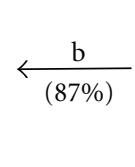<smiles>O=C1C=CCN1Cc1ccccc1</smiles>

8

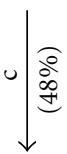<smiles>O=C(/C=C/CNCc1ccccc1)NCc1ccccc1</smiles>

11

$+$<smiles>O=C(/C=C/CNCc1ccccc1)NCc1ccccc1</smiles>

12

$+$<smiles>O=C(C/C=C/NCc1ccccc1)NCc1ccccc1</smiles>

13 

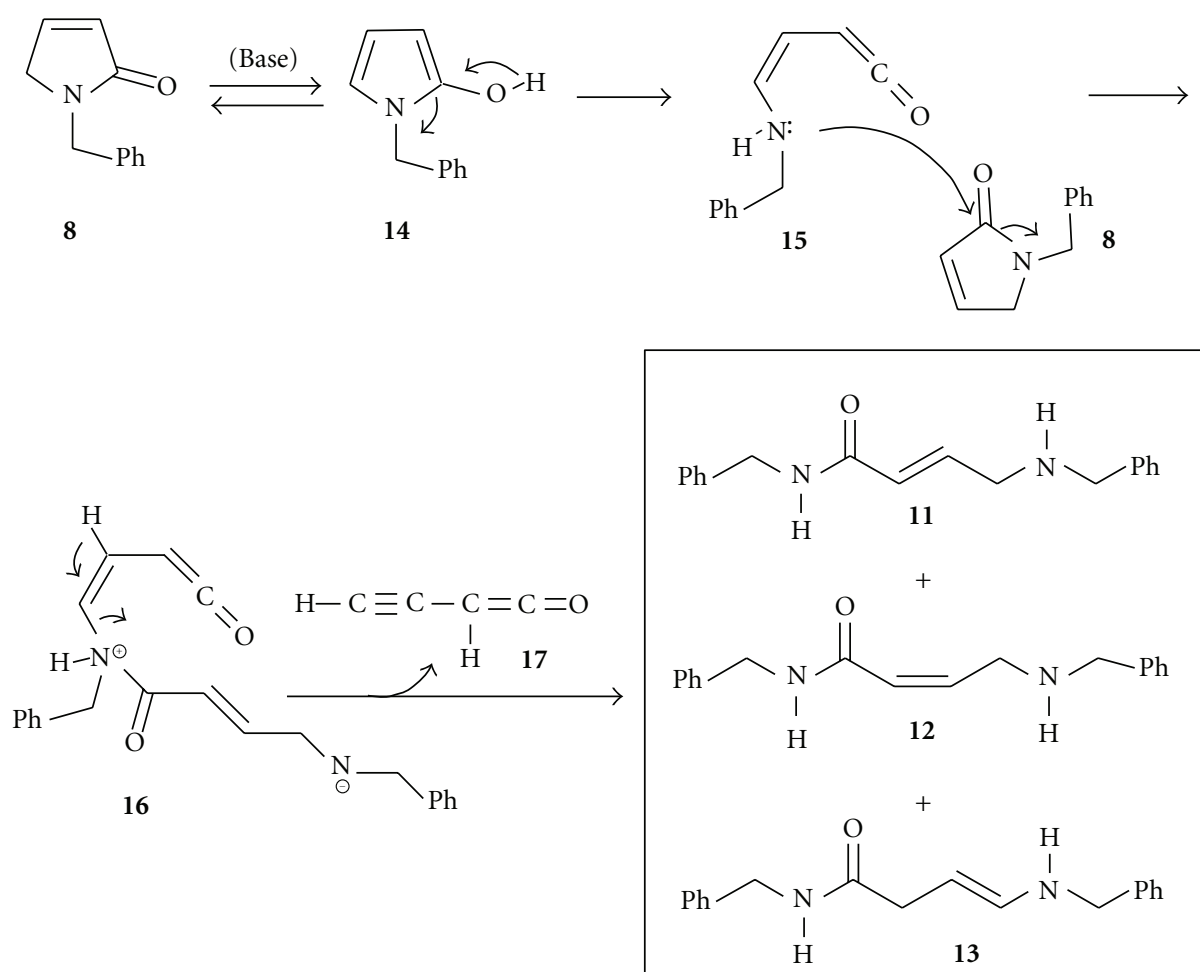

F. W. $280 \mathrm{~g} \mathrm{~mol}^{-1}$

Base $=$ S- $\alpha$-methylbenzylamine

Scheme 5: Speculative mechanism for reaction of lactam 8 with $S$ - $\alpha$-methylbenzylamine.

compound $\mathbf{1 8}$ as the major product, previously described [1], after purification over column chromatography of silica gel. An apolar fraction was also isolated and identified by ${ }^{1} \mathrm{H}$ NMR and ${ }^{13} \mathrm{C}$ NMR as the byproduct $19(10: 1)$ and $61 \%$ of general yield. The increase of yield observed in this reaction, accomplished in milligram scale, was attributed to the better homogeneity of the reagents that usually occurs in these conditions. We propose that compound 19 was obtained as result of in situ acylation of the enol form derived from lactam 18 with (Boc) $)_{2} \mathrm{O}$. That kind of equilibrium between 3 pyrrolin-2-ones and their enol forms, in basic medium, was previously described [15].

2.6. Conjugate Addition Reactions of Some Nucleophiles to Ntert-butoxycarbonyl-3-pyrrolin-2-one. As we have described in previous publication [1], the conjugate addition reaction of nitromethane to $\alpha, \beta$-unsaturated system of $N$-tert-butoxycarbonyl-3-pyrrolin-2-one(18) proceeded in smooth conditions. We planned to use compound $\mathbf{1 8}$ as substrate for accomplishment of that conjugate addition reaction with other nucleophiles, based on previous experiments reported in the literature. Thus, the addition of amines [15] and malonate anion [16] to $\alpha, \beta$-unsaturated system of 18 was evaluated. The results from these addition reactions are displayed in Table 3 with the respective products analysed by NMR.
TABLE 2: ${ }^{1} \mathrm{H}$ NMR data of the isomers $\mathbf{4 a}$ and $\mathbf{4 b}$.

\begin{tabular}{lcc}
\hline Hydrogens & 4a & $\mathbf{4 b}$ \\
& $\delta$ (Multiplicity, J/Hz) & $\delta$ (Multiplicity, J/Hz) \\
\hline N-H & $6.55(\mathrm{bs})$ & $6.90(\mathrm{bs})$ \\
\hline C3-H & $4.46(\mathrm{dd}, 2.4$ and 7.3) & $4.32(\mathrm{dd}, 4.9$ and 7.5) \\
\hline \multirow{2}{*}{ C4-H } & $2.76-2.50(\mathrm{~m})$ & $2.78-2.50(\mathrm{~m})$ \\
& $2.42-2.24(\mathrm{~m})$ & $2.42-2.24(\mathrm{~m})$ \\
\hline \multirow{2}{*}{ C5-H } & \multirow{2}{*}{$3.50-3.24(\mathrm{~m})$} & $3.65-3.48(\mathrm{~m})$ \\
& & $3.48-3.25(\mathrm{~m})$ \\
\hline
\end{tabular}

The mixture of compounds obtained in experiment 1 suggests that addition of benzylamine was initially performed on the carbamate at the lactamic ring of $\mathbf{1 8}$ to yield a product of opening of the $\gamma$-lactam, amide 21 . This compound underwent subsequent in situ reaction of conjugate addition with benzylamine to furnish amide 22 . In experiment 2 the reaction was accomplished without $\mathrm{H}_{2} \mathrm{O}$, and a mixture of isomers $\mathbf{2 4}$ was obtained. The product from experiment 3 was identified by ${ }^{1} \mathrm{H}$ NMR and ${ }^{13} \mathrm{C}$ NMR as a mixture of isomers 26.

2.7. Protection of the Lactamic Nitrogen on 4-phenyl-2pyrrolidinone. The protection of the lactamic nitrogen on 


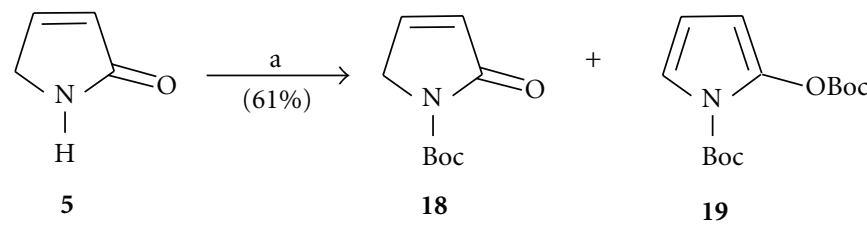

$(10: 1)$

Scheme 6: Reagents and conditions: (a) DMAP (0.05 equiv), (Boc) $)_{2} \mathrm{O}$ (1.1 equiv), THF (r.t., 10 min).

TABLE 3: Reactions of lactam 18 with some nucleophiles.

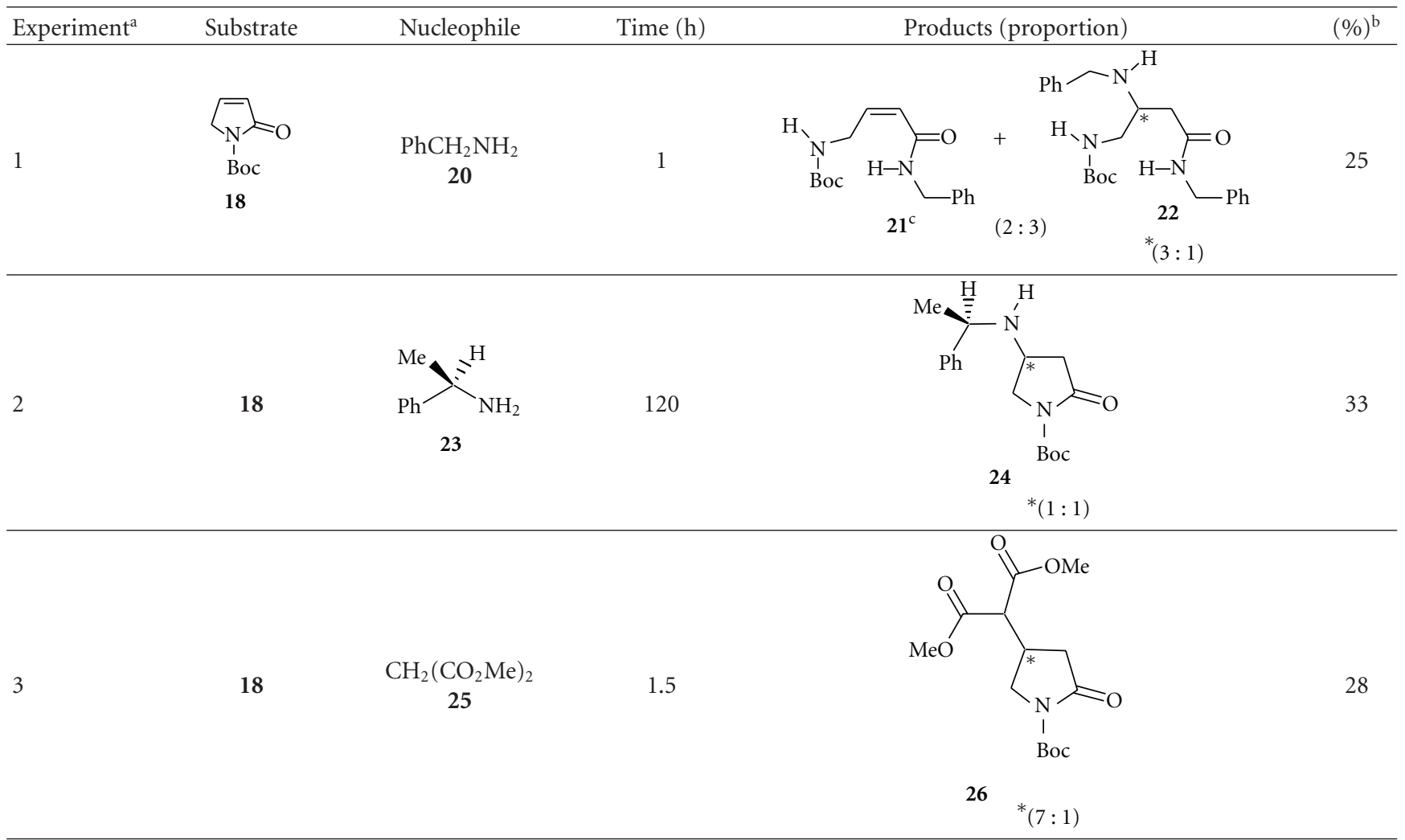

Reagents: Experiment 1: $\mathrm{PhCH}_{2} \mathrm{NH}_{2}$ (1.7 equiv), $\mathrm{H}_{2} \mathrm{O}$ (5.0 equiv); Experiment 2: $R$ - $\alpha$-methylbenzylamine (1.2 equiv), THF; Experiment 3: $\mathrm{CH}_{2}\left(\mathrm{CO}_{2} \mathrm{Me}_{2}\right.$ (1.1 equiv), $\mathrm{MeONa}\left(0.4\right.$ equiv), $\mathrm{MeOH} .{ }^{a}$ The experiments were performed at room temperature. ${ }^{\mathrm{b}}$ After purification over column chromatography of silica gel. ${ }^{c}$ Four isomers were detected at the ${ }^{1} \mathrm{H}$ NMR spectrum in the proportion $(2: 1: 10: 2)$, measured by integrals relative to signals of hydrogens of the groups tert-butoxycarbonyl [ $\delta 1.52$ (minor), $\delta 1.51$ (minor), $\delta 1.47$ (major), $\delta 1.43$ (minor)]. ${ }^{*}$ The proportions of the mixtures of isomers were measured at the ${ }^{1} \mathrm{H}$ NMR spectra by integrals relative to signals of hydrogens of the groups tert-butoxycarbonyl: Experiment 1 [ $\delta 1.52$ (minor), $\delta 1.43$ (major)]; Experiment 2 [ $\delta$ $1.52, \delta 1.48]$; Experiment 3 [ $\delta 1.52$ (major), $\delta 1.45$ (minor)].

4-phenyl-2-pyrrolidinone(27), previously obtained [17], was performed in the conditions described in Scheme 7. In conditions a we used as deprotonating agent the base $\mathrm{NaH}$, and the generated amide ion was acylated with $(\mathrm{Boc})_{2} \mathrm{O}[3]$. In conditions $\mathbf{b}$ we used the base $\mathrm{KH}$ with catalytic amount of the crown ether 18-crown-6 [18] and with benzyl bromide as alkylating agent. Products $\mathbf{2 8}$ and $\mathbf{2 9}$ were identified by ${ }^{1} \mathrm{H}$ NMR, ${ }^{13} \mathrm{C}$ NMR, IR, and LRMS.

\section{Conclusions}

In summary, the chemical reactivity of 2-pyrrolidinones and 3-pyrrolin-2-ones was evaluated in different reaction conditions. The reactions presented in this paper led to the preparation of functionalized $\gamma$-lactams, and, therefore, they can be useful for future studies with these classes of substances.

\section{Experimental}

Infrared spectra were recorded on a Perkin Elmer-1600 model 1605 spectrophotometer $(\mathrm{KBr})$. NMR spectra were recorded on a Varian Gemini-200 $\left({ }^{1} \mathrm{H}: 200 \mathrm{MHz}\right.$ and ${ }^{13} \mathrm{C}$ : $50.3 \mathrm{MHz}$ ) spectrometer, using $\mathrm{CDCl}_{3}$ as the solvent and TMS as internal standard. Coupling constants $(J)$ are reported in Hertz $(\mathrm{Hz})$, and multiplicities are indicated as singlet (s), broad singlet (bs), doublet (d), broad doublet (bd), double doublet (dd), triplet $(\mathrm{t})$, and multiplet $(\mathrm{m})$. 


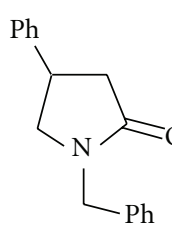

29

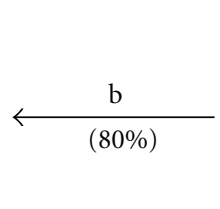

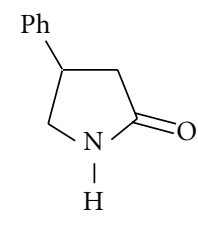

27

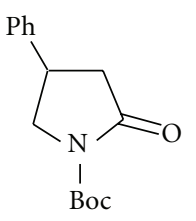

28

Scheme 7: Reagents and conditions: (a) (i) $\mathrm{NaH}$ (1.2 equiv), THF (r.t., 10 min), (ii) (Boc) 2 O (1.4 equiv, r.t., 20 min); (b) (i) KH (1.5 equiv), 18-crown-6 (0.5 equiv), THF (r.t., 5 min), (ii) Bn-Br (1.2 equiv, r.t., 10 min).

Low-resolution mass spectra (LRMS) were obtained by electron impact $(70 \mathrm{eV})$ on a Varian GC-MS Saturn 2000 spectrometer. Thin-layer chromatography was performed on aluminium sheets coated with $60 \mathrm{~F}_{254}$ silica and visualization by UV light and/or for contact of the plates with $7 \%$ ethanolic solution of phosphomolybdic acid and posterior heating. The purifications by column chromatography were performed on silica gel (230-400 mesh). The solvents and reagents were dried and purified by usual procedures [19].

4.1. 2-Pyrrolidinone(1). It is used as starting material to obtain some compounds. $\mathrm{R}_{\mathrm{f}} 0.18$ (EtOAc). ${ }^{1} \mathrm{H}$ NMR $\left(200 \mathrm{MHz}, \mathrm{CDCl}_{3}\right): \delta 6.61$ (bs, $\left.1 \mathrm{H}\right), 3.40(\mathrm{~m}, 2 \mathrm{H}), 2.36-2.22$ (m, 2H), 2.22-2.03 (m, 2H).

4.2. N-(tert-butoxycarbonyl)-2-pyrrolidinone(2). 2-Pyrrolidinone $(\mathbf{1})(2.000 \mathrm{~g}, 23.500 \mathrm{mmol})$ was added to a stirred suspension of $\mathrm{NaH}(0.677 \mathrm{~g}, 28.200 \mathrm{mmol})$ in THF $(47 \mathrm{~mL})$, at room temperature and nitrogen atmosphere. After 15 minutes, (Boc) ${ }_{2} \mathrm{O}(6.154 \mathrm{~g}, 28.200 \mathrm{mmol})$ was added and the mixture was stirred at room temperature and nitrogen atmosphere for 40 minutes. Saturated solution of $\mathrm{NH}_{4} \mathrm{Cl}$ $(60 \mathrm{~mL})$ was added and then extracted with EtOAc $(2 \times$ $200 \mathrm{~mL})$. The organic extracts were dried with $\mathrm{Na}_{2} \mathrm{SO}_{4}$, filtered, and concentrated in vacuum. The crude product was purified over column chromatography of silica gel eluted with 30\% EtOAc/hexane and crescent gradient of EtOAc (50 and 100\%). A colourless oil was obtained (3.043 g, $70 \%)$, characterized as the pyrrolidinone $2 . \mathrm{R}_{\mathrm{f}} 0.33(50 \%$ EtOAc/hexane). ${ }^{1} \mathrm{H}$ NMR $\left(200 \mathrm{MHz}, \mathrm{CDCl}_{3}\right): \delta 3.75(\mathrm{~m}$, $2 \mathrm{H}), 2.51(\mathrm{~m}, 2 \mathrm{H}), 2.00(\mathrm{~m}, 2 \mathrm{H}), 1.53(\mathrm{~s}, 9 \mathrm{H})$.

\section{3. $N$-(tert-butoxycarbonyl)-3-thiophenoxy-2-pyrrolidinone} (3). $n$-BuLi $1.85 \mathrm{~mol} \mathrm{~L}^{-1}(3.0 \mathrm{~mL}, 5.520 \mathrm{mmol})$ was added dropwise to a stirred solution of diisopropylamine $(0.55 \mathrm{~mL}$, $3.940 \mathrm{mmol})$ in THF $(26 \mathrm{~mL})$ at $0^{\circ} \mathrm{C}$ and stirred for 20 minutes under nitrogen atmosphere. The stirred solution was put on a bath at $-78^{\circ} \mathrm{C}$, and the pyrrolidinone $2(0.552 \mathrm{~g}$, $2.820 \mathrm{mmol})$ in THF $(2.8 \mathrm{~mL})$ was added. After 30 minutes $(\mathrm{PhS})_{2}(0.860 \mathrm{~g}, 3.94 \mathrm{mmol})$ in THF $(39 \mathrm{~mL})$ was added and left under magnetic stirring, $-78^{\circ} \mathrm{C}$ and nitrogen atmosphere for 15 minutes, and then at room temperature for $2 \mathrm{~h}$. The mixture was concentrated in vacuum, diluted with EtOAc $(50 \mathrm{~mL})$, and then washed with saturated solution of $\mathrm{NH}_{4} \mathrm{Cl}(1 \times 50 \mathrm{~mL})$ and $\mathrm{H}_{2} \mathrm{O}(1 \times 50 \mathrm{~mL})$. The organic layer was separated, and the aqueous phases were extracted with EtOAc $(2 \times 50 \mathrm{~mL})$. The organic extracts were dried with $\mathrm{Na}_{2} \mathrm{SO}_{4}$, filtered, and concentrated in vacuum. The crude product was purified over column chromatography of silica gel eluted with $20 \%$ EtOAc/hexane. Pyrrolidinone $3(0.070 \mathrm{~g}, 16 \%)$ was obtained as a colourless oil, and substrate $2(0.247 \mathrm{~g}, 47 \%)$ was recovered without reacting. Pyrrolidinone 3: $\mathrm{R}_{\mathrm{f}} 0.61$ (50\% EtOAc/hexane). ${ }^{1} \mathrm{H}$ NMR $\left(200 \mathrm{MHz}, \mathrm{CDCl}_{3}\right): \delta 7.60-7.45(\mathrm{~m}, 2 \mathrm{H}), 7.40-7.30(\mathrm{~m}$, $3 \mathrm{H}), 3.90-3.80(\mathrm{~m}, 1 \mathrm{H}), 3.70-3.45(\mathrm{~m}, 2 \mathrm{H}), 2.55-2.25(\mathrm{~m}$, $1 \mathrm{H}), 2.15-1.90(\mathrm{~m}, 1 \mathrm{H}), 1.52(\mathrm{~s}, 9 \mathrm{H})$. Minor isomer: $\delta 1.43$ (s, 9H).

4.4. 3-iodine-2-pyrrolidinone(4a): Kinetic Product. To a solution of 2-pyrrolidinone $(1)(0.569 \mathrm{~g}, 6.686 \mathrm{mmol})$ in $\mathrm{CH}_{2} \mathrm{Cl}_{2}$ $(15 \mathrm{~mL})$ at $-15^{\circ} \mathrm{C}$ and magnetic stirring, $\mathrm{Et}_{3} \mathrm{~N}(4.7 \mathrm{~mL}$, $33.430 \mathrm{mmol})$ and then TMSCl $(2.5 \mathrm{~mL}, 20.058 \mathrm{mmol})$ were added. After 10 minutes, $\mathrm{I}_{2}(3.394 \mathrm{~g}, 13.372 \mathrm{mmol})$ in $\mathrm{CH}_{2} \mathrm{Cl}_{2}(20 \mathrm{~mL})$ was added, and the mixture was transferred to a bath at $0^{\circ} \mathrm{C}$. After $2 \mathrm{~h}$, the mixture was washed with aqueous solution of $10 \% \mathrm{Na}_{2} \mathrm{SO}_{3}(2 \times 100 \mathrm{~mL})$ and then saturated solution of $\mathrm{NaCl}(1 \times 100 \mathrm{~mL})$. The organic layer was separated, and the aqueous phases were extracted with $\mathrm{CH}_{2} \mathrm{Cl}_{2}(3 \times 100 \mathrm{~mL})$. The organic extracts were dried with $\mathrm{Na}_{2} \mathrm{SO}_{4}$, filtered, and concentrated in vacuum. The crude product was purified over column chromatography of silica gel eluted with EtOAc. A yellowish crystalline residue was obtained $(0.352 \mathrm{~g}, 25 \%)$ characterized as 3-iodine-2pyrrolidinone $(4 \mathbf{a}+4 \mathbf{b} / 5: 1)$. Major product $(4 a): \mathrm{R}_{\mathrm{f}} 0.23$ (EtOAc). ${ }^{1} \mathrm{H}$ NMR $\left(200 \mathrm{MHz}, \mathrm{CDCl}_{3}\right)$ : Table 2.

4.5. 3-iodine-2-pyrrolidinone(4b): Thermodynamic Product (Experiment 1, Table 1). A mixture of 3-iodine-2-pyrrolidinone $(4 \mathbf{a}+4 \mathbf{b} / 5: 1)(0.060 \mathrm{~g}, 0.284 \mathrm{mmol}), \mathrm{LiCl}(0.060 \mathrm{~g}$, $1.415 \mathrm{mmol})$, and DMF $(1.4 \mathrm{~mL})$ was heated at $100^{\circ} \mathrm{C}$, under magnetic stirring and nitrogen atmosphere for $5 \mathrm{~h}$. The mixture was concentrated in vacuum, diluted with $\mathrm{CH}_{2} \mathrm{Cl}_{2}(20 \mathrm{~mL})$, and then washed with $\mathrm{H}_{2} \mathrm{O}(1 \times 20 \mathrm{~mL})$. The organic layer was separated, and the aqueous phase was extracted with $\mathrm{CH}_{2} \mathrm{Cl}_{2}(1 \times 30 \mathrm{~mL})$. The organic extracts were dried with $\mathrm{Na}_{2} \mathrm{SO}_{4}$, filtered, and concentrated in vacuum. The crude product was purified over column chromatography of silica gel eluted with EtOAc. A colourless crystalline residue $(0.024 \mathrm{~g}, 40 \%)$ was obtained characterized as 3-iodine-2-pyrrolidinone $(4 \mathbf{a}+4 \mathbf{b} / 1: 10)$. Major product (4b): $\mathrm{R}_{\mathrm{f}} 0.30$ (EtOAc). ${ }^{1} \mathrm{H}$ NMR $\left(200 \mathrm{MHz}, \mathrm{CDCl}_{3}\right)$ : Table 2. 
4.6. Elimination Reaction Performed with Lactam 4 : (Experiment 2, Table 1). A mixture of 3-iodine-2-pyrrolidinone $(4 \mathbf{a}+4 \mathbf{b} / 5: 1) \quad(0.037 \mathrm{~g}, 0.175 \mathrm{mmol}), \mathrm{Et}_{3} \mathrm{~N} \quad(0.12 \mathrm{~mL}$, $0.875 \mathrm{mmol})$, and $\mathrm{CH}_{3} \mathrm{CN}(0.5 \mathrm{~mL})$ was stirred at $25^{\circ} \mathrm{C}$ for $72 \mathrm{~h}$. The mixture was concentrated in vacuum, diluted with EtOAc $(20 \mathrm{~mL})$, and then washed with saturated solution of $\mathrm{NH}_{4} \mathrm{Cl}(1 \times 30 \mathrm{~mL})$ and $\mathrm{H}_{2} \mathrm{O}(1 \times 30 \mathrm{~mL})$. The organic layer was separated, and the aqueous phases were extracted with EtOAc $(1 \times 30 \mathrm{~mL})$. The organic extracts were dried with $\mathrm{Na}_{2} \mathrm{SO}_{4}$, filtered, and concentrated in vacuum. The crude product was purified over column chromatography of silica gel eluted with EtOAc and 10\% $\mathrm{MeOH} /$ EtOAc. A brownish oil $(0.014 \mathrm{~g}, 41 \%)$ was obtained characterized by ${ }^{1} \mathrm{H}$ NMR as a mixture of 3-iodine-2-pyrrolidinone $(4 \mathbf{a}+4 \mathbf{b})$ and 3 pyrrolin-2-one(5), previously described [1], in a respective proportion of $(1: 5: 1)$.

4.7. Elimination Reaction Performed with Lactam 4: (Experiment 3, Table 1). A mixture of 3-iodine-2-pyrrolidinone $(4 \mathbf{a}+4 \mathbf{b} / 5: 1) \quad(0.046 \mathrm{~g}, 0.218 \mathrm{mmol}), \mathrm{Et}_{3} \mathrm{~N} \quad(0.15 \mathrm{~mL}$, $1.09 \mathrm{mmol})$, and $\mathrm{CH}_{3} \mathrm{CN}(0.6 \mathrm{~mL})$ under magnetic stirring and nitrogen atmosphere was heated at $85^{\circ} \mathrm{C}$ for $3 \mathrm{~h}$. The mixture was concentrated in vacuum, diluted with EtOAc $(20 \mathrm{~mL})$, and then washed with saturated solution of $\mathrm{NH}_{4} \mathrm{Cl}$ $(1 \times 20 \mathrm{~mL})$ and $\mathrm{H}_{2} \mathrm{O}(1 \times 20 \mathrm{~mL})$. The organic layer was separated, and the aqueous phases were extracted with EtOAc $(1 \times 30 \mathrm{~mL})$. The organic extracts were dried with $\mathrm{Na}_{2} \mathrm{SO}_{4}$, filtered, and concentrated in vacuum. The crude product was purified over column chromatography of silica gel eluted with 50\% EtOAc/hexane and EtOAc. A colourless crystalline residue was obtained $(0.012 \mathrm{~g}, 27 \%)$ characterized as 3-iodine-2-pyrrolidinone $(\mathbf{4 b})\left(\mathrm{R}_{\mathrm{f}} 0.30\right.$, EtOAc) and a brownish oil $(0.003 \mathrm{~g}, 13 \%)$ characterized as 3-pyrrolin-2one(5), previously described [1].

4.8. $\mathrm{N}$-(tert-butoxycarbonyl)-2-hydroxy-pyrrolidine(6). $\mathrm{NaBH}_{4}$ $(0.012 \mathrm{~g}, 0.317 \mathrm{mmol})$ was added to a solution of the pyrrolidinone $2(0.053 \mathrm{~g}, 0.286 \mathrm{mmol})$ in $\mathrm{MeOH}(1.0 \mathrm{~mL})$. The mixture was left under magnetic stirring, room temperature, and nitrogen atmosphere for $5 \mathrm{~h} . \mathrm{H}_{2} \mathrm{O}(30 \mathrm{~mL})$ was added and then extracted with $\mathrm{CH}_{2} \mathrm{Cl}_{2}(2 \times 50 \mathrm{~mL})$. The organic extracts were dried with $\mathrm{Na}_{2} \mathrm{SO}_{4}$, filtered, and concentrated in vacuum. The crude product was purified over column chromatography of silica gel eluted with $50 \% \mathrm{EtOAc/hexane}$ and EtOAc. A colourless oil $(0.040 \mathrm{~g}, 75 \%)$ was obtained characterized as the hemiaminal 6. $\mathrm{R}_{\mathrm{f}} 0.22(60 \% \mathrm{EtOAc} /$ hexane). ${ }^{1} \mathrm{H}$ NMR $\left(200 \mathrm{MHz}, \mathrm{CDCl}_{3}\right): \delta 4.66$ (bs, $\left.1 \mathrm{H}\right), 3.67$ $(\mathrm{m}, 2 \mathrm{H}), 3.15(\mathrm{~m}, 2 \mathrm{H}), 1.58(\mathrm{~m}, 3 \mathrm{H}), 1.44(\mathrm{~s}, 9 \mathrm{H})$.

4.9. $N$-(tert-butoxycarbonyl)-3-( $\alpha$-hydroxy-benzyl)-2-pyrrolidinone(7). n-BuLi $1.41 \mathrm{~mol} \mathrm{~L}^{-1}(1.15 \mathrm{~mL}, 1.621 \mathrm{mmol})$ was added dropwise to a stirred solution of diisopropylamine $(0.21 \mathrm{~mL}, 1.498 \mathrm{mmol})$ in $\mathrm{THF}(5.0 \mathrm{~mL})$ at $0^{\circ} \mathrm{C}$ and stirred for 10 minutes under nitrogen atmosphere. The stirred solution was put in a bath at $-78^{\circ} \mathrm{C}$, and pyrrolidinone $2(0.248 \mathrm{~g}, 1.339 \mathrm{mmol})$ in THF $(6.0 \mathrm{~mL})$ was added. After 30 minutes, benzaldehyde $(0.15 \mathrm{~mL}, 1.475 \mathrm{mmol})$ was added dropwise, and the mixture was left at $-78^{\circ} \mathrm{C}$ for $2.5 \mathrm{~h}$ and then at room temperature for $1 \mathrm{~h}$. Aqueous solution of $10 \%$ $\mathrm{HCl}(\mathrm{v} / \mathrm{v})$ was added until $\mathrm{pH} 1$, and the mixture was transferred to a separatory funnel, diluted with EtOAc $(50 \mathrm{~mL})$, and then washed with $\mathrm{H}_{2} \mathrm{O}(1 \times 50 \mathrm{~mL})$. The organic layer was separated, and the aqueous phase was extracted with EtOAc $(1 \times 50 \mathrm{~mL})$. The organic extracts were dried with $\mathrm{Na}_{2} \mathrm{SO}_{4}$, filtered, and concentrated in vacuum. The crude product was purified over column chromatography of silica gel eluted with hexane and crescent gradient of EtOAc (70 and $100 \%)$. A colourless crystalline residue was obtained $(0.114 \mathrm{~g}, 29 \%)$ characterized as a mixture of isomers $7 . \mathrm{R}_{\mathrm{f}}$ 0.27 (EtOAc). ${ }^{1} \mathrm{H}$ NMR $\left(200 \mathrm{MHz}, \mathrm{CDCl}_{3}\right): \delta 7.55-7.28(\mathrm{~m}$, $5 \mathrm{H}), 7.23$ (bs, $1 \mathrm{H}, \mathrm{D}_{2} \mathrm{O}$ exchange), 3.57 (t, J $\left.6.5 \mathrm{~Hz}, 2 \mathrm{H}\right)$, $3.28(\mathrm{~m}, 1 \mathrm{H}), 3.22-3.10(\mathrm{~m}, 2 \mathrm{H}), 1.80(\mathrm{~m}, 1 \mathrm{H}), 1.41(\mathrm{~s}, 9 \mathrm{H})$. Minor isomers: $\delta 7.25-7.20\left(\mathrm{~m}, 1 \mathrm{H}, \mathrm{D}_{2} \mathrm{O}\right.$ exchange), 6.80 (bs, $1 \mathrm{H}, \mathrm{D}_{2} \mathrm{O}$ exchange), 6.60 (bs, $1 \mathrm{H}, \mathrm{D}_{2} \mathrm{O}$ exchange), 4.83 (bd, J $7.5 \mathrm{~Hz}, 1 \mathrm{H}), 4.72(\mathrm{~d}, J 9.6 \mathrm{~Hz}, 1 \mathrm{H}), 3.32-3.23(\mathrm{~m}, 1 \mathrm{H}), 2.86$ $(\mathrm{m}, 1 \mathrm{H}), 2.71(\mathrm{~m}, 1 \mathrm{H}), 1.44(\mathrm{~s}, 9 \mathrm{H})$.

\subsection{N-benzyl-2-hydroxy-pyrrolidine(9)}

4.10.1. Preparation of the Grignard Reagent. A mixture of magnesium $(0.027 \mathrm{~g}, 1.111 \mathrm{mmol})$, bromobenzene $(0.11 \mathrm{~mL}$, $1.044 \mathrm{mmol})$, and THF $(5.0 \mathrm{~mL})$ was heated at reflux, under magnetic stirring and argon atmosphere for $3 \mathrm{~h}$. It was then allowed to cool at room temperature, and the recently prepared solution of the Grignard reagent was used in the following reaction.

4.10.2. Reaction of $\mathrm{PhMgBr}-\mathrm{CuBr} \cdot \mathrm{SMe}_{2}$ with N-benzyl-3pirrolin-2-one (8), TMSCl/THF. The recently prepared solution of the Grignard reagent $(5.0 \mathrm{~mL})$ was added to a stirred suspension of $\mathrm{CuBr} \cdot \mathrm{SMe}_{2}(0.031 \mathrm{~g}, 0.151 \mathrm{mmol})$ in THF $(0.5 \mathrm{~mL})$ at room temperature and stirred for 10 minutes under argon atmosphere. The stirred mixture was put in a bath at $-78^{\circ} \mathrm{C}$, and then a solution of lactam $8(0.116 \mathrm{~g}$, $0.669 \mathrm{mmol})$ and TMSCl $(0.17 \mathrm{~mL}, 1.339 \mathrm{mmol})$ in THF $(2.0 \mathrm{~mL})$ was added. The mixture was left at $-78^{\circ} \mathrm{C}$ for $3 \mathrm{~h}$ and then allowed to reach the room temperature. The mixture was transferred to a separatory funnel, and EtOAc $(40 \mathrm{~mL})$ was added and then washed with saturated solution of $\mathrm{NH}_{4} \mathrm{Cl}(1 \times 20 \mathrm{~mL})$. The organic layer was separated, and the aqueous phase was extracted with EtOAc $(1 \times 40 \mathrm{~mL})$. The organic extracts were dried with $\mathrm{Na}_{2} \mathrm{SO}_{4}$, filtered, and concentrated in vacuum. The crude product was purified over column chromatography of silica gel eluted with EtOAc. A brownish crystalline residue was obtained characterized as compound $9(0.078 \mathrm{~g}, 66 \%)$. $\mathrm{R}_{\mathrm{f}} 0.24$ (EtOAc). IR ( $\left.\mathrm{KBr}\right)$ $\nu_{\max } / \mathrm{cm}^{-1}: 3172,2927,1643,1448,1331,1259,1076,996$, 946, 700. ${ }^{1} \mathrm{H}$ NMR $\left(200 \mathrm{MHz}, \mathrm{CDCl}_{3}\right): \delta 7.38-7.24(\mathrm{~m}, 5 \mathrm{H})$, $5.08(\mathrm{~m}, 1 \mathrm{H}), 4.83(\mathrm{~d}, J 14.7 \mathrm{~Hz}, 1 \mathrm{H}), 4.20(\mathrm{~d}, J 14.7 \mathrm{~Hz}, 1 \mathrm{H})$, 3.21 (bd, J 7.2 Hz, 1H, $\mathrm{D}_{2} \mathrm{O}$ exchange), 2.72-2.50 (m, $\left.2 \mathrm{H}\right)$, 2.46-2.16 (m, 3H), 2.06-1.80 (m, $1 \mathrm{H}) . \mathrm{m} / \mathrm{z}(\%): 177\left(\mathrm{M}^{+}\right.$, 1\%), 173 (100), 91 (100), 65 (30).

4.11. N-benzyl-2-pyrrolidinone(10). A mixture of lactam 8 $(0.100 \mathrm{~g}, 0.577 \mathrm{mmol}), 20 \% \mathrm{Pd}(\mathrm{OH})_{2} / \mathrm{C}(0.041 \mathrm{~g}, 0.0577$ $\mathrm{mmol})$, and $\mathrm{MeOH}(6.0 \mathrm{~mL})$, inside a round-bottom flask, 
was submitted to hydrogen atmosphere (balloon) under magnetic stirring and room temperature for $12 \mathrm{~h}$. The mixture was filtered, concentrated in vacuum, and then purified over column chromatography of silica gel eluted with EtOAc. A brownish oil was obtained characterized as the lactam 10 (0.088 g, 87\%). R 0.47 (EtOAc). ${ }^{1} \mathrm{H}$ NMR (200 MHz, $\left.\mathrm{CDCl}_{3}\right): \delta 7.39-7.20(\mathrm{~m}, 5 \mathrm{H}), 4.45(\mathrm{~s}, 2 \mathrm{H}), 3.26(\mathrm{~m}, 2 \mathrm{H})$, $2.45(\mathrm{~m}, 2 \mathrm{H}), 1.99(\mathrm{~m}, 2 \mathrm{H})$.

4.12. Mixture of the Probable Isomers 11-13. A solution of lactam $8(0.102 \mathrm{~g}, 0.589 \mathrm{mmol})$ in $S$ - $\alpha$-methylbenzylamine $(0.5 \mathrm{~mL}, 3.878 \mathrm{mmol})$ was left under magnetic stirring, room temperature, and nitrogen atmosphere for $72 \mathrm{~h}$. The mixture was transferred to a separatory funnel, diluted with EtOAc $(30 \mathrm{~mL})$, and then washed with aqueous $10 \% \mathrm{HCl}(\mathrm{v} / \mathrm{v})$ $(1 \times 20 \mathrm{~mL})$ and $\mathrm{H}_{2} \mathrm{O}(1 \times 20 \mathrm{~mL})$. The organic layer was separated, and the aqueous phases were extracted with EtOAc $(1 \times 30 \mathrm{~mL})$. The organic extracts were dried with $\mathrm{Na}_{2} \mathrm{SO}_{4}$, filtered, and concentrated in vacuum. The crude product was purified over column chromatography of silica gel eluted with hexane and 50\% EtOAc/hexane. A colourless oil was obtained characterized as a mixture of the probable isomers 11-13 (0.079 g, 48\%). $\mathrm{R}_{\mathrm{f}} 0.30$ (50\% EtOAc/hexane). IR $(\mathrm{KBr}) v_{\max } / \mathrm{cm}^{-1}: 3418,2924,1743,1689,1613,1496$, 1429, 1396, 1339, 1292, 1254, 1188, 1129, 1061, 1014, 930, 871, 823, 696, 626, 522, 458, 433, 408. ${ }^{1} \mathrm{H}$ NMR $(200 \mathrm{MHz}$, $\left.\mathrm{CDCl}_{3}\right): \delta 7.44-7.20(\mathrm{~m}), 7.10-7.00(\mathrm{~m}), 4.93(\mathrm{~s}), 4.63(\mathrm{~s})$, $3.50(\mathrm{dd}, J 1.7$ and $3.5 \mathrm{~Hz}), 3.46(\mathrm{~m}), 3.45(\mathrm{dd}, J 1.7$ and $3.5 \mathrm{~Hz}), 3.43(\mathrm{t}, J 1.7 \mathrm{~Hz}), 3.26(\mathrm{t}, J 1.7 \mathrm{~Hz}), 3.24(\mathrm{~d}, J 7.7 \mathrm{~Hz})$, 2.80-2.60 (m). ${ }^{13} \mathrm{C} \mathrm{NMR}\left(50 \mathrm{MHz}, \mathrm{CDCl}_{3}\right): \delta 177.67(\mathrm{C}=\mathrm{O})$, $173.38(\mathrm{C}=\mathrm{O}), 170.56(\mathrm{C}=\mathrm{O}), 152.27(\mathrm{C}), 135.97$ (C), 135.73 (C), $129.19(\mathrm{CH}), 128.69(\mathrm{CH}), 128.45(\mathrm{CH}), 127.75(\mathrm{CH})$, $127.69(\mathrm{CH}), 125.05(\mathrm{CH}), 96.12(\mathrm{C}), 44.36\left(\mathrm{CH}_{2}\right), 41.94$ $\left(\mathrm{CH}_{2}\right), 32.93\left(\mathrm{CH}_{2}\right), 27.45\left(\mathrm{CH}_{2}\right), 25.40\left(\mathrm{CH}_{2}\right) . \mathrm{m} / \mathrm{z}(\%)\left(\mathrm{T}_{\mathrm{R}}\right.$ $2.1 \mathrm{~min}, \mathrm{GC}): 281(\mathrm{M}+1,15 \%), 264$ (5), 247 (3), 225 (3), 209 (18), 191 (5), 179 (5), 167 (8), 147 (35), 132 (100), 105 (85), 91 (22), 77 (90), 55 (63). m/z (\%) ( $\left.\mathrm{T}_{\mathrm{R}} 7.4 \mathrm{~min}, \mathrm{GC}\right): 281$ $(\mathrm{M}+1,8 \%), 267$ (3), 243 (1), 209 (5), 189 (100), 173 (10), 160 (45), 149 (10), 132 (35), 119 (25), 104 (38), 91 (28), 77 (20), 65 (15), $51(18) . \mathrm{m} / \mathrm{z}(\%)\left(\mathrm{T}_{\mathrm{R}} 8.4 \mathrm{~min}, \mathrm{GC}\right): 281(\mathrm{M}+$ 1, 13\%), 264 (3), 249 (1), 225 (2), 209 (10), 189 (15), 173 (85), 160 (8), 146 (20), 132 (5), 118 (8), 104 (28), 91 (100), 77 (15), 65 (28), 55 (15), 44 (18).

4.13. N-(tert-butoxycarbonyl)-3-pyrrolin-2-one(18) and N,2$O$-[bis(tert-butoxycarbonyl)]-pyrrole(19). This reaction was performed by previously described procedure [1], starting from 3-pyrrolin-2-one(5) (0.654 g, $7.876 \mathrm{mmol})$. After purification of crude product over column chromatography of silica gel eluted with 30\% EtOAc/hexane and crescent gradient of EtOAc (50 and 100\%), lactam 18 (0.802 g, 55.5\%), previously described [1] [ $\mathrm{R}_{\mathrm{f}} 0.29$ (50\% EtOAc/hexane)], was obtained. A colourless oil was also isolated and characterized as compound $19(0.124 \mathrm{~g}, 5.5 \%)$. Compound 19: $\mathrm{R}_{\mathrm{f}} 0.66$ (50\% EtOAc/hexane). ${ }^{1} \mathrm{H}$ NMR $\left(200 \mathrm{MHz}, \mathrm{CDCl}_{3}\right): \delta 6.94$ (dd, $J 2.0$ and $3.7 \mathrm{~Hz}, 1 \mathrm{H}$ ), 6.04 (dd, J 3.6 and $3.7 \mathrm{~Hz}, 1 \mathrm{H}$ ), $5.84(\mathrm{dd}, J 2.0$ and $3.6 \mathrm{~Hz}, 1 \mathrm{H}), 1.57(\mathrm{~s}, 9 \mathrm{H}), 1.55(\mathrm{~s}, 9 \mathrm{H})$. ${ }^{13} \mathrm{C} \mathrm{NMR}\left(50 \mathrm{MHz}, \mathrm{CDCl}_{3}\right): \delta 150.88(\mathrm{C}=\mathrm{O}), 147.43(\mathrm{C}=\mathrm{O})$,
$136.88(\mathrm{C}), 116.33(\mathrm{CH}), 107.95(\mathrm{CH}), 100.23(\mathrm{CH}), 84.03$ (C), $83.74(\mathrm{C}), 27.68\left(3 \mathrm{CH}_{3}\right), 27.34\left(3 \mathrm{CH}_{3}\right)$.

4.14. N-benzyl-4-amino(tert-butoxycarbonyl)-2-butenamide (21) and N-benzyl-3-aminobenzyl-4-amino(tert-butoxy-carbonyl)-butanamide(22) (Experiment 1, Table 3). $\mathrm{H}_{2} \mathrm{O}(0.03$ $\mathrm{mL}, 1.665 \mathrm{mmol})$ was added to a solution of lactam 18 $(0.059 \mathrm{~g}, \quad 0.322 \mathrm{mmol})$ in benzylamine $(0.06 \mathrm{~mL}, 0.549$ $\mathrm{mmol})$, under magnetic stirring, at room temperature and nitrogen atmosphere. After $1 \mathrm{~h}$ the mixture was concentrated in vacuum, diluted with $\mathrm{CH}_{2} \mathrm{Cl}_{2}(1.0 \mathrm{~mL})$, transferred with a pipette to the top of a column chromatography of silica gel, and then eluted with hexane and crescent gradient of EtOAc (10, 50, and 100\%). Butenamide 21 (0.009 g, 10\%) was obtained as a colourless oil. $\mathrm{R}_{\mathrm{f}} 0.46$ (70\% EtOAc/hexane). ${ }^{1} \mathrm{H} \mathrm{NMR}\left(200 \mathrm{MHz}, \mathrm{CDCl}_{3}\right): \delta 7.54-7.40(\mathrm{~m}, 1 \mathrm{H}), 7.40-$ $7.14(\mathrm{~m}, 5 \mathrm{H}), 6.66(\mathrm{~m}, 1 \mathrm{H}), 6.02(\mathrm{~m}, 1 \mathrm{H}), 4.66(\mathrm{~m}, 1 \mathrm{H})$, $4.43(\mathrm{~d}, J 5.7 \mathrm{~Hz}, 2 \mathrm{H}), 2.93(\mathrm{~m}, 2 \mathrm{H}), 1.47$ (s, 9H). Minor isomers: $\delta 1.52(\mathrm{~s}, 9 \mathrm{H}), 1.51(\mathrm{~s}, 9 \mathrm{H}), 1.43(\mathrm{~s}, 9 \mathrm{H})$. Butanamide $22(0.019 \mathrm{~g}, 15 \%)$ was obtained as a colourless oil. $\mathrm{R}_{\mathrm{f}} 0.23$ (70\% EtOAc/hexane). ${ }^{1} \mathrm{H}$ NMR $\left(200 \mathrm{MHz}, \mathrm{CDCl}_{3}\right): \delta 7.83$ (m, 1H), 7.40-7.12 (m, 10H), $4.92(\mathrm{~m}, 1 \mathrm{H}), 4.41(\mathrm{~m}, 2 \mathrm{H})$, $3.85(\mathrm{~m}, 1 \mathrm{H}), 3.79(\mathrm{~m}, 2 \mathrm{H}), 3.26(\mathrm{~m}, 2 \mathrm{H}), 3.06(\mathrm{~m}, 1 \mathrm{H}), 2.34$ (m, 2H), $1.43(\mathrm{~s}, 9 \mathrm{H})$. Minor isomer: $\delta 1.52(\mathrm{~s}, 9 \mathrm{H})$.

4.15. N-(tert-butoxycarbonyl), $4[N(R)$ - $\alpha$-methylbenzylamine]-2-pyrrolidinone(24) (Experiment 2, Table 3). $R$ - $\alpha$-methylbenzylamine $(0.05 \mathrm{~mL}, 0.388 \mathrm{mmol})$ was added to a solution of lactam $18(0.056 \mathrm{~g}, 0.306 \mathrm{mmol})$ in THF $(0.5 \mathrm{~mL})$, under magnetic stirring, at room temperature and nitrogen atmosphere. After $120 \mathrm{~h}$, the mixture was concentrated in vacuum, diluted with $\mathrm{CH}_{2} \mathrm{Cl}_{2}(1.5 \mathrm{~mL})$, transferred with a pipette to the top of a column chromatography of silica gel, and then eluted with hexane and crescent gradient of EtOAc (50 and 100\%). A colourless oil was obtained characterized as a mixture $(1: 1)$ of isomers $24(0.031 \mathrm{~g}, 33 \%)$. $\mathrm{R}_{\mathrm{f}} 0.36(70 \%$ EtOAc/hexane). ${ }^{1} \mathrm{H}$ NMR $\left(200 \mathrm{MHz}, \mathrm{CDCl}_{3}\right): \delta 7.40-7.20$ (m, 10H), 3.90-3.50 (m, 6H), 3.42-3.15 (m, 4H), 2.74-2.14 (m, 4H), 1.52 (s, 9H), 1.48 (s, 9H), 1.36 (d, J 6.6 Hz, 6H).

4.16. N-(tert-butoxycarbonyl)-4-(dimethyl malonyl)-2-pyrrolidinone(26) (Experiment 3, Table 3). Dimethyl malonate $(0.04 \mathrm{~mL}, 0.35 \mathrm{mmol})$ was added to a stirred solution of $\mathrm{MeONa}[\mathrm{Na}(0.003 \mathrm{~g}, 0.130 \mathrm{mmol}), \mathrm{MeOH}(0.2 \mathrm{~mL})]$ at room temperature and nitrogen atmosphere. After $10 \mathrm{~min}$ utes, lactam 18 (0.053 g, $0.289 \mathrm{mmol})$ in $\mathrm{MeOH}(0.5 \mathrm{~mL})$ was added and the mixture was left under magnetic stirring, at room temperature and nitrogen atmosphere for $1.5 \mathrm{~h}$. The mixture was concentrated in vacuum, diluted with EtOAc $(20 \mathrm{~mL})$, and then washed with saturated solution of $\mathrm{NH}_{4} \mathrm{Cl}(1 \times 30 \mathrm{~mL})$. The organic layer was separated, and the aqueous phase was extracted with EtOAc $(1 \times 30 \mathrm{~mL})$. The organic extracts were dried with $\mathrm{Na}_{2} \mathrm{SO}_{4}$, filtered, and concentrated in vacuum. The crude product was purified over column chromatography of silica gel eluted with hexane and crescent gradient of EtOAc (20 and 30\%). A colourless oil was obtained characterized as a mixture of isomers 26 (0.026 g, 28\%). $\mathrm{R}_{\mathrm{f}} 0.35$ (50\% EtOAc/hexane). ${ }^{1} \mathrm{H}$ NMR 
$\left(200 \mathrm{MHz}, \mathrm{CDCl}_{3}\right): \delta 4.07(\mathrm{~d}, J 8.0 \mathrm{~Hz}, 1 \mathrm{H}), 3.80(\mathrm{~s}, 3 \mathrm{H})$, $3.70(\mathrm{~s}, 3 \mathrm{H}), 3.38(\mathrm{~m}, 2 \mathrm{H}), 3.11(\mathrm{~m}, 1 \mathrm{H}), 2.54(\mathrm{~m}, 2 \mathrm{H}), 1.52$ $(\mathrm{s}, 9 \mathrm{H})$. Minor isomers: $\delta 4.12(\mathrm{~d}, J 8.0 \mathrm{~Hz}, 1 \mathrm{H}), 3.76(\mathrm{~d}, J$ $3.9 \mathrm{~Hz}, 1 \mathrm{H}), 3.68$ (d, J 4.4 Hz, 1H), 1.45 (s, 9H). ${ }^{13} \mathrm{C}$ NMR $\left(50 \mathrm{MHz}, \mathrm{CDCl}_{3}\right): \delta 170.93(\mathrm{C}=\mathrm{O}), 168.17(\mathrm{C}=\mathrm{O}), 167.38$ $(\mathrm{C}=\mathrm{O}), 149.45(\mathrm{C}=\mathrm{O}), 83.59(\mathrm{C}), 55.42(\mathrm{CH}), 52.80\left(\mathrm{CH}_{3}\right)$, $51.84\left(\mathrm{CH}_{3}\right), 49.51\left(\mathrm{CH}_{2}\right), 36.52\left(\mathrm{CH}_{2}\right), 31.10(\mathrm{CH}), 27.82$ $\left(3 \mathrm{CH}_{3}\right)$.

4.17. N-(tert-butoxycarbonyl)-4-phenyl-2-pyrrolidinone(28). 4-Phenyl-2-pyrrolidinone(27) (0.213 g, $1.321 \mathrm{mmol})$ in THF $(9.5 \mathrm{~mL})$ was added to a stirred suspension of $\mathrm{NaH}(0.038 \mathrm{~g}$, $1.583 \mathrm{mmol})$ in THF $(1.5 \mathrm{~mL})$, at room temperature and nitrogen atmosphere. After 10 minutes, (Boc) $)_{2} \mathrm{O}(0.407 \mathrm{~g}$, $1.865 \mathrm{mmol}$ ) was added and the mixture was left under magnetic stirring, at room temperature and nitrogen atmosphere for 20 minutes. Saturated solution of $\mathrm{NH}_{4} \mathrm{Cl}(50 \mathrm{~mL})$ was added, and then extracted with EtOAc $(2 \times 50 \mathrm{~mL})$. The organic extracts were dried with $\mathrm{Na}_{2} \mathrm{SO}_{4}$, filtered, and concentrated in vacuum. The crude product was purified over column chromatography of silica gel eluted with $20 \%$ EtOAc/hexane. A yellowish crystalline residue was obtained characterized as pyrrolidinone $28(0.207 \mathrm{~g}, 60 \%) . \mathrm{R}_{\mathrm{f}} 0.50$ (50\% EtOAc/hexane). IR (KBr) $\nu_{\max } / \mathrm{cm}^{-1}: 2978,1774,1694$, 1493, 1457, 1366, 1296, 1255, 1155, 1092, 1019, 839, 766, 701. ${ }^{1} \mathrm{H}$ NMR $\left(200 \mathrm{MHz}, \mathrm{CDCl}_{3}\right): \delta 7.43-7.21(\mathrm{~m}, 5 \mathrm{H}), 4.24-4.10$ (m, 1H), 3.76-3.44 (m, 2H), 3.00-2.62 (m, 2H), 1.53 (s, 9H). Minor isomer: $\delta 1.41(\mathrm{~s}, 9 \mathrm{H}),{ }^{13} \mathrm{C} \mathrm{NMR}\left(50 \mathrm{MHz}, \mathrm{CDCl}_{3}\right)$ : $\delta 172.69(\mathrm{C}=\mathrm{O}), 149.53(\mathrm{C}=\mathrm{O}), 140.26(\mathrm{C}), 128.63(2 \mathrm{CH})$, $127.07(\mathrm{CH}), 126.42(2 \mathrm{CH}), 82.64(\mathrm{C}), 52.80\left(\mathrm{CH}_{2}\right), 39.95$ $\left(\mathrm{CH}_{2}\right), 36.05(\mathrm{CH}), 27.69\left(3 \mathrm{CH}_{3}\right) . \mathrm{m} / \mathrm{z}(\%): 263(\mathrm{M}+2$, 1\%), 206 (13), 162 (48), 132 (20), 104 (100), 78 (33).

4.18. N-benzyl-4-phenyl-2-pyrrolidinone(29). 18-Crown-6 $(0.066 \mathrm{~g}, 0.250 \mathrm{mmol})$ in THF $(0.2 \mathrm{~mL})$ and 4-phenyl-2pyrrolidinone $(27)(0.080 \mathrm{~g}, 0.496 \mathrm{mmol})$ in THF $(0.7 \mathrm{~mL})$ were added to a stirred suspension of $\mathrm{KH}(0.030 \mathrm{~g}$, $0.748 \mathrm{mmol})$ in THF $(0.1 \mathrm{~mL})$ at room temperature and nitrogen atmosphere. After 5 minutes, benzyl bromide $(0.104 \mathrm{~g}, 0.608 \mathrm{mmol})$ was added and the mixture was left under magnetic stirring, at room temperature and nitrogen atmosphere for 10 minutes. Saturated solution of $\mathrm{NH}_{4} \mathrm{Cl}$ $(15 \mathrm{~mL})$ was added, and the mixture was extracted with EtOAc $(2 \times 20 \mathrm{~mL})$. The organic extracts were dried with $\mathrm{Na}_{2} \mathrm{SO}_{4}$, filtered, and concentrated in vacuum. The crude product was purified over column chromatography of silica gel eluted with 30\% EtOAc/hexane. A colourless crystalline residue was obtained characterized as pyrrolidinone 29 $(0.100 \mathrm{~g}, 80 \%) . \mathrm{R}_{\mathrm{f}} 0.45$ (EtOAc). IR (KBr) $\nu_{\max } / \mathrm{cm}^{-1}: 3027$, 2929, 2848, 1691, 1668, 1492, 1425, 1248, 850, 746, 698, 664, 609, 524. ${ }^{1} \mathrm{H}$ NMR $\left(200 \mathrm{MHz}, \mathrm{CDCl}_{3}\right): \delta 7.40-7.10$ $(\mathrm{m}, 10 \mathrm{H}), 4.56(\mathrm{~d}, J 14.6 \mathrm{~Hz}, 1 \mathrm{H}), 4.44(\mathrm{~d}, J 14.6 \mathrm{~Hz}, 1 \mathrm{H})$, 3.68-3.42 (m, 2H), 3.38-3.16 (m, 1H), 2.95-2.78 (m, 1H), 2.68-2.52 (m, 1H). ${ }^{13} \mathrm{C} \mathrm{NMR}\left(50 \mathrm{MHz}, \mathrm{CDCl}_{3}\right): \delta 173.40$ $(\mathrm{C}=\mathrm{O}), 142.00(\mathrm{C}), 136.07(\mathrm{C}), 128.54(2 \mathrm{CH}), 128.47$ (2 $\mathrm{CH}), 127.96(2 \mathrm{CH}), 127.41(\mathrm{CH}), 126.75(\mathrm{CH}), 126.43(2$ $\mathrm{CH}), 53.49\left(\mathrm{CH}_{2}\right), 46.34\left(\mathrm{CH}_{2}\right), 38.65\left(\mathrm{CH}_{2}\right), 36.90(\mathrm{CH})$. m/z (\%): $251\left(\mathrm{M}^{+}, \mathrm{l}, 100 \%\right), 160$ (35), $146(20), 120$ (13), 104 (48), 91 (45), 78 (15), 65 (15), 51 (10).

See the supplementary material displaying the speculative mechanisms for the reactions presented in the text of the paper. The supplementary material is available online at doi: $10.1155 / 2011 / 803120$.

\section{Acknowledgments}

J. C. F. Alves thanks UFRJ (PRONEX: 41.96.0888.00/01) and FAPERJ (E-26/150.293/2001) for financial support, NPPNUFRJ for NMR spectra, and Department of Chemistry (UFRRJ) for infrared and mass spectra.

\section{References}

[1] J. C. F. Alves, "Preliminary studies towards the preparation of reactive 3-pyrrolin-2-ones in conjugate addition reactions for the syntheses of potentially bioactive 2-pyrrolidinones and pyrrolidines," Journal of the Brazilian Chemical Society, vol. 18, no. 4, pp. 855-859, 2007.

[2] E. Santaniello, D. Vaghi, and A. Manzocchi, "A ready synthesis of some $\mathrm{N}$-substituted 3-alkoxycarbonyl-2-pyrrolinones," Synthetic Communications, vol. 9, no. 2, pp. 619-624, 1979.

[3] M. Dobler, J. C. Anderson, M. Juch, and H. J. Borschberg, "Synthesis of Aristotelia-type alkaloids. Part XV. Total synthesis of (+)-hobartinol," Helvetica Chimica Acta, vol. 78, no. 2, pp. 292-300, 1995.

[4] F. Kido, K. Tsutsumi, R. Maruta, and A. Yoshikoshi, "Lactone annulation of $\beta$-keto esters with $\beta$-vinylbutenolide and the total synthesis of racemic frullanolide," Journal of the American Chemical Society, vol. 101, no. 21, pp. 6420-6424, 1979.

[5] A. McKillop, D. Koyuncu, A. Krief, W. Dumont, P. Renier, and M. Trabelsi, "Efficient, high yield oxidation of thiols and selenols to disulphides and diselenides," Tetrahedron Letters, vol. 31, no. 35, pp. 5007-5010, 1990.

[6] A. O. King, R. Kevin Anderson, R. F. Shuman, S. Karady, N. Lee Abramson, and A. W. Douglas, "Iodotrimethylsilanemediated 2-monohalogenation of 4-aza- $5 \alpha$-androstan-3-one steroids," The Journal of Organic Chemistry, vol. 58, no. 12, pp. 3384-3386, 1993.

[7] J. D. Armstrong III, K. K. Eng, J. L. Keller et al., "An efficient asymmetric synthesis of (R)-3-amino-2,3,4,5-tetrahydro- $1 \mathrm{H}$ [1]benzazepin-2-one," Tetrahedron Letters, vol. 35, no. 20, pp. 3239-3242, 1994.

[8] R. P. Holyzs, "Preparation and dehydrohalogenation of 4halo-3-ketosteroids," Journal of the American Chemical Society, vol. 75 , no. 18 , pp. 4432-4437, 1953.

[9] B. H. Lee and M. F. Clothier, "Selective reduction of secondary amides to amines in the presence of tertiary amides," Tetrahedron Letters, vol. 40, no. 4, pp. 643-644, 1999.

[10] G. Stork, G. A. Kraus, and G. A. Garcia, "Regiospecific aldol condensations of the kinetic lithium enolates of methyl ketones," The Journal of Organic Chemistry, vol. 39, no. 23, pp. 3459-3460, 1974.

[11] Y. Horiguchi, S. Matsuzawa, E. Nakamura, and I. Kuwajima, " $\mathrm{Me}_{3} \mathrm{SiCl} / \mathrm{HMPA}$ accelerated conjugate addition of catalytic copper reagent. Stereoselective synthesis of enol silyl ether of aldehyde," Tetrahedron Letters, vol. 27, no. 34, pp. 4025-4028, 1986. 
[12] A. Diaz, J. G. Siro, J. L. García-Navío, J. J. Vaquero, and J. Alvarez-Builla, "A stereoselective synthesis of (R)-(-)-rolipram from L-glutamic acid," Synthesis, no. 5, pp. 559-562, 1997.

[13] I. Baussanne and J. Royer, "Stereoselective synthesis of 4,5disubstituted pyrrolidin-2-ones by cuprate addition to chiral non racemic $\alpha, \beta$-unsaturated- $\gamma$-lactams," Tetrahedron Letters, vol. 39, no. 8, pp. 845-848, 1998.

[14] F. Degiorgis, M. Lombardo, and C. Trombini, "Synthesis of four stereoisomers of 5-amino-2,5-dideoxy-heptono-1,5lactams," Tetrahedron, vol. 53, no. 34, pp. 11721-11730, 1997.

[15] N. Langlois, O. Calvez, and M. O. Radom, "Stereocontrolled synthesis of enantiopure substituted 4-aminopyrrolidin-2ones," Tetrahedron Letters, vol. 38, no. 46, pp. 8037-8040, 1997.

[16] M. Asaoka, S. Sonoda, N. Fujii, and H. Takei, "Diastereoselective 1,4-addition of various nucleophiles to 5-trimethylsilyl-2cyclohexenone: synthesis of (+)-ramulosin," Tetrahedron, vol. 46, no. 5, pp. 1541-1552, 1990.

[17] J. L. O. Domingos, "Synthesis of pyrrolidines, 2pyrrolidinones and potentially bioactive 5-isoxazolidinones," Ph.D. thesis, NPPN, Universidade Federal do Rio de Janeiro, Rio de Janeiro, Brazil, 2004.

[18] K. Soai, A. Ookawa, and K. Kato, "A facile one-pot synthesis of $\mathrm{N}$-substituted phthalimides using a catalytic amount of crown ether," Bulletin of the Chemical Society of Japan, vol. 55, no. 5, pp. 1671-1672, 1982.

[19] D. D. Perrin, W. L. F. Armarego, and D. R. Perrin, Purification of Laboratory Chemicals, Pergamon Press, New York, NY, USA, 2nd edition, 1980. 


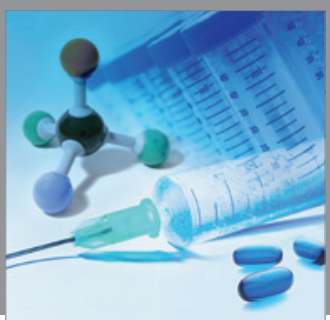

International Journal of

Medicinal Chemistry

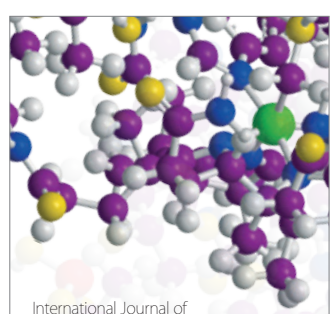

Carbohydrate Chemistry

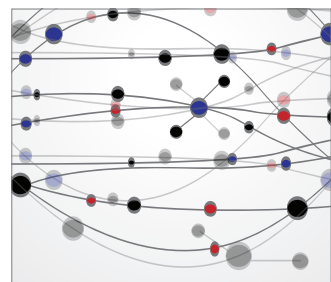

The Scientific World Journal
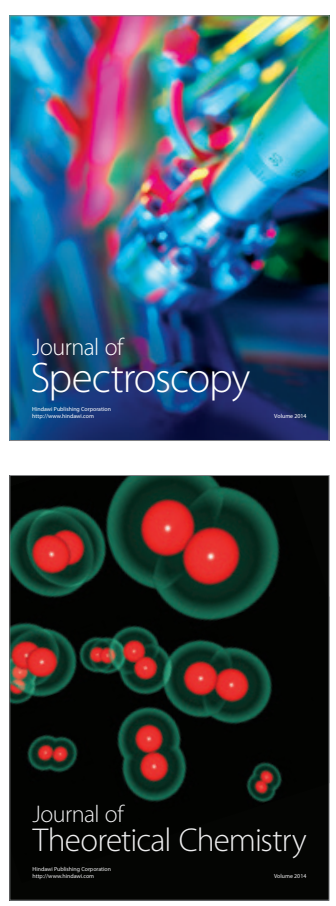
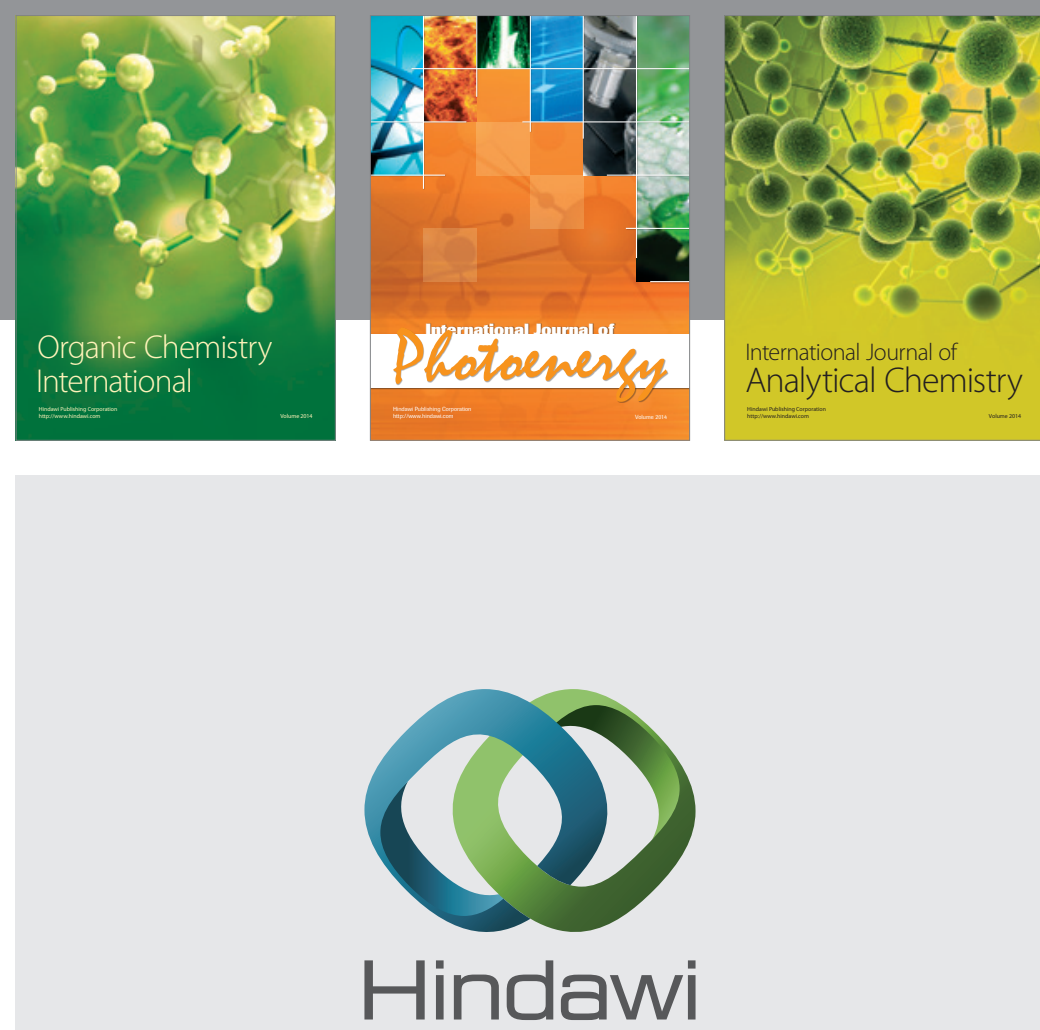

Submit your manuscripts at

http://www.hindawi.com
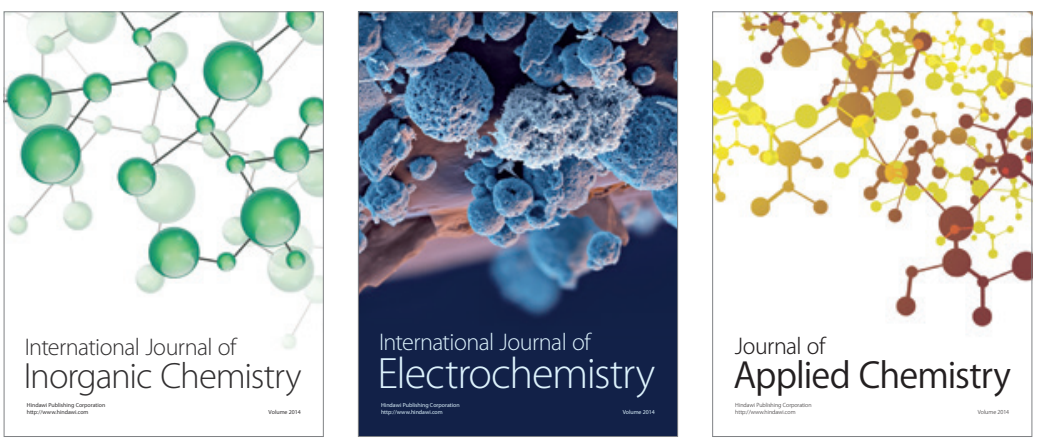

Journal of

Applied Chemistry
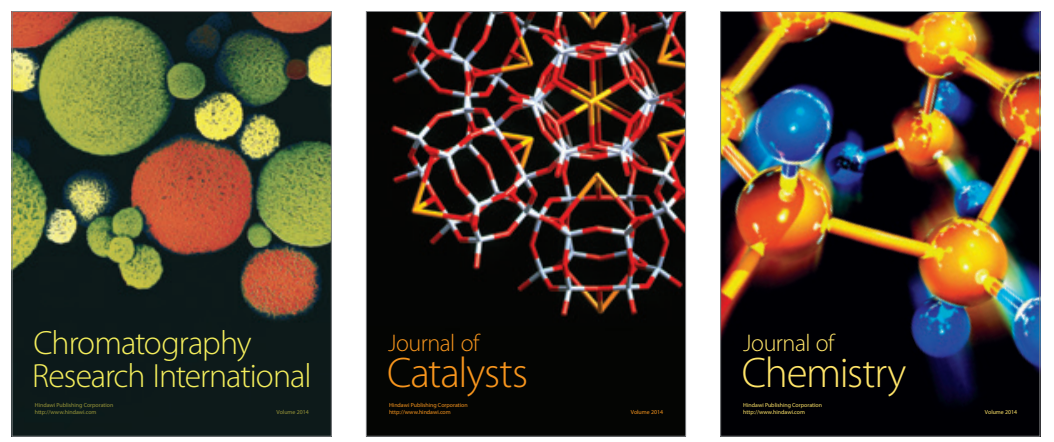
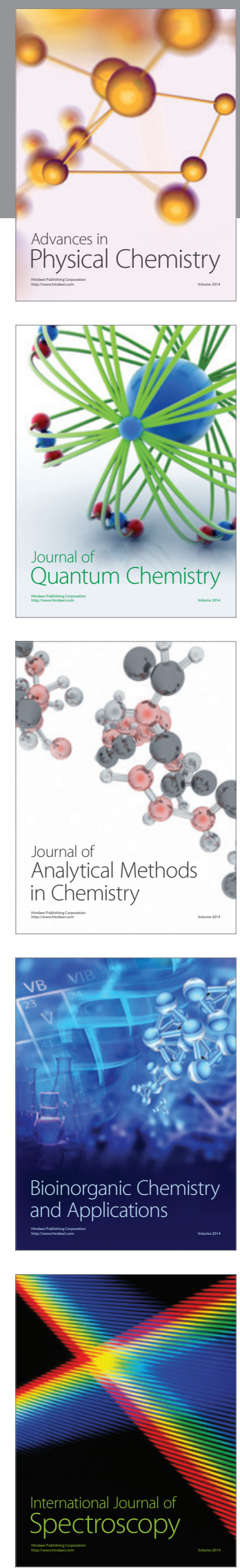